\title{
Microbiological analysis and antibacterial activity of pear samples
}

\author{
Habiba Afroz, Tasnia Ahmed and Md. Aftab Uddin* \\ Department of Microbiology, Stamford University Bangladesh, 51 Siddeswari Road, Dhaka 1217, \\ Bangladesh
}

Received 12 January 2015/Accepted 08 March 2015

\begin{abstract}
Present study attempted to isolate and quantify the microorganisms from the pear samples collected within Dhaka metropolis. Out of the five samples studied, total viable bacterial count and the total coliform count were near about $10^{5} \mathrm{cfu} / \mathrm{g}$ and $10^{4} \mathrm{cfu} / \mathrm{g}$, respectively. Among the specific pathogens, prevalence of Salmonella spp. and Vibrio spp. were found only in two samples. Whereas Klebsiella spp, Pseudomonas spp. and Staphylococcus aureus were detected in all the samples studied. Fungal growth was also observed in each sample within the range of $8.8 \times 10^{4}-9.5 \times 10^{4} \mathrm{cfu} / \mathrm{g}$. The study of antibiogram revealed that, most of the pathogens were resistant to more than one antibiotic. Interestingly the pear samples showed no anti-bacterial activity against any of the laboratory isolates such as, Escherichia coli, Pseudomonas spp., Salmonella spp. and Bacillus spp.
\end{abstract}

Key words: Pear, Pathogens; Fungal growth; Antibiogram; Anti-bacterial activity

The horticultural products particularly fruits contain vitamins, minerals, simple sugars and fibers that covers the needs of everyday people (1) and if their remedial and nutritional values are known then they can be used for both prevention and cure of diseases (2). Scientific data indicate that several degenerative diseases such as cardiovascular problems and various cancers can be prevented upon consumption of fruits and vegetables (3). However, as a result of unsuitable management and storage environment, the chance of microbial spoilage and diseases of a product increases by pathogenic and/or deteriorative microorganisms (4). The nature of fruits and vegetables is influenced by post harvest handling, transportation, storage and marketing because they are highly delicate products. [6] Indeed, intake of fresh-cut fruits and unpasteurized juices has lead to a number of outbreaks and cases of illness in the last years (5).

According to the report of WHO (1996) (7), the key factor of high mortality rates in developing countries is the infectious diseases. Several food borne pathogens such as Escherichia coli, Salmonella spp., Listeria monocytogenes, Aeromonas spp., Staphylococcus spp., Streptococcus spp., Vibrio spp. and Pseudomonas are responsible for various disease, morbidity and mortality (8).

The presence of Mycotoxins is also a matter of safety concern connected with foods. These are secondary metabolites of filamentous fungi; the most responsible and unsafe are species of the Penicillium and Aspergillus genera (8). They fall into the category of

${ }^{*}$ Corresponding Author: Mailing address. Md. Aftab Uddin, Department of Microbiology, Stamford University Bangladesh, 51 Siddeswari Road, Dhaka 1217, Bangladesh ; E-mail: aftab_mb12@yahoo.com. opportunistic microflora, with high possibilities of colonization since the harvesting period of horticultural products, when the $\mathrm{pH}$ of the tissue increased, the skin layers became soften and soluble carbohydrates build up and defense barriers is weaken (9). Now a day's treatment of various diseases is becoming difficult because of the emergence of drug resistant pathogens that may be introduced into the host because of the consumption of contaminated food (10-14). In recent years, many antibiotics have lost their effectiveness due to development of resistant strains as a result of the expression of resistance genes or spontaneous mutations within the microbial populations (15-19). This situation has contributed to the development of alternative antimicrobial drugs which are highly effective and non toxic, derived entirely from natural sources (20). Eventually, natural products with the healing properties has gained the interests of scientist community (21). Because of the presence of many active phytochemicals such as polyhenols, anthocyanins, flavonoids, terpenoids, carotenoids, cumarins, saponin and vitamins, fruits are becoming potential alternatives in the treatment of many diseases instead of using the antimicrobial agents (22-24).

Based on these facts and considerations, the current research focuses to ascertain and enumerate the pear spoiling microorganisms with their drug resistant traits and to reveal anti-bacterial activity of the samples tested.

\section{MATERIALS AND METHODS}

Selection of study area $\&$ collection of fruit samples for investigation. Samples were collected from some popular super shops from five areas of Dhaka city such as Rampura, Khilgao, Shantinagar, Moghbazar and Mailbagh areas. Samples were collected in different time intervals and transported to the laboratory as soon as possible according to the method suggested by American Public Health Association (25). For the identification \& enumeration of pathogenic bacteria \& fungi, at first $10 \mathrm{~g}$ of each sample was taken, then blended with $90 \mathrm{ml}$ normal saline 
( $\mathrm{pH} 7.8$ ) \& diluted up to $10^{-4} \&$ then dilutions were used for plating purposes according to the standard guideline (26).

Enumeration of total viable bacteria \& fungi. The enumeration was performed by using $0.1 \mathrm{ml}$ of each sample onto nutrient agar (NA) \& Sabouraud Dextrose Agar (SDA) for the determination of total viable bacterial count (TVBC) and total fungal load respectively by the spread plate technique. The plates were incubated at $37{ }^{\circ} \mathrm{C}$ for 24 hours and at $25^{\circ} \mathrm{C}$ for 48 hours for TVBC \& total fungal load respectively.

Estimation of total coliform.. From the dilution $10^{-2} \& 10^{-3}$, the $0.1 \mathrm{ml}$ sample was spread onto MacConkey agar for the detection of total coliform. The plates were incubated at $37{ }^{\circ} \mathrm{C}$ for 24 hours.

Isolation of Salmonella spp., Shigella \& Vibrio spp. The $1 \mathrm{ml}$ sample was transferred into $9 \mathrm{ml}$ of seleniote cysteine broth (SCB) and alkaline peptone wate (APW) for the enrichment of Salmonella, Shigella and Vibrio spp. respectively \& incubated at $37{ }^{\circ} \mathrm{C}$ for 6 hours. After enrichment the samples were diluted up to $10^{-4} \&$ then $0.1 \mathrm{ml}$ of samples from $10^{-2} \& 10^{-3}$ were spread onto Salmonella Shigella (SS) agar \& Thiosulfate Citrate Bile Salt Sucrose (TCBS) agar followed by incubation at $37{ }^{\circ} \mathrm{C}$ for 24 hours for the detection of the colony characteristics. For the identification, the biochemical trait of the isolates was tested following standard biochemical methods $(10,11,26)$.

Isolation of Staphylococcus spp., Pseudomonas spp.. Staphylococcus \& Pseudomonus spp were isolated from the Mannitol Salt Agar (MSA) \& Pseudomonas agar respectively by spreading $0.1 \mathrm{ml}$ of the diluted samples on these media \& then incubated at $37^{\circ} \mathrm{C}$ for 24 hours.

Biochemical tests for the confirmative identification. Finally, the standard biochemical tests were performed to confirm the identification of all the pathogenic isolates found in all 5 types of pear samples by the previously described methods $(26,27)$.

Antibiotic susceptibility test. The pathogenic isolates were examined for antibiotic susceptibility traits (either drug resisistant or sensitive) by disc diffusion assay on Muller-Hinton agar (MHA) (Difco, Detroit, MI) against commonly used antibiotics following the standard protocol. Antibiotics used in the study are, Ampicillin $(10 \mu \mathrm{g})$, Amoxicillin $(10 \mu \mathrm{g})$, Ciprofloxacin $(5 \mu \mathrm{g})$, Ceftriaxone $(30 \mu \mathrm{g})$, Nalidixic acid $(30 \mu \mathrm{g})$, Imipenem $(30 \mu \mathrm{g})$, Erythromycin $(15 \mu \mathrm{g})$, Chloramphenicol $(10 \mu \mathrm{g})$, Trimethoprime-sulfomethoxazole $(25 \mu \mathrm{g})$, Gentamicin $(10 \mu \mathrm{g}) \&$ Piperaciline $(10 \mu \mathrm{g})(28)$.

Determination of antibacterial activity of the fruit sample. The antibacterial activity of the fruit samples was performed by using agar well diffusion method. Briefly, fruit blends were used directly on the Mueller-Hinton agar (MHA) media. At first, the bacterial pathogens (Pseudomonas spp, Bacillus spp, Salmonella spp, E. coli) were introduced evenly over the MHA separately using cotton swab, followed by making hole in the MHA by cork borer. Each of the blends was then introduced separately in the specified hole with a positive control (antibiotic discGentamicin (GEN) 10 $\mu$ g) \& a negative control (normal saline). Presence of clear zone around the sample solution (if any) indicated the presence of antibacterial activity (29-31).

\section{RESULTS AND DISCUSSIONS}

Most of the fruits are eaten raw and may lead to the outbreaks of human diseases that may put the overall public health at a serious risk. Various types of health related problems are associated with the proliferation of etiological agents as well as their drug-resistance properties (32). Along these lines, the present study portrays the (1) pathogenic load different types of pears consumed in Bangladesh, (2) Antibiogram profile of the pathogens, and finally (3) the antibacterial activities of these pear samples.

Prevalence of pathogenic microorganisms. Several previous studies showed that Escherichia coli, Salmonella spp., Shigella spp., Staphylococcus aureus, Vibrio spp. and fungi were common in a varieties of fruits and vegetables samples $(13,33)$. The load of Vibrio spp., Salmonella spp. and Shigella spp. were nil before enrichment; however, after enrichment Vibrio spp. was estimated within a range of $2.0 \times 10^{4}-8.3 \times 10^{7} \mathrm{cfu} / \mathrm{g}$ while Salmonella and Shigella spp. were found in between $1.0 \times 10^{3}-3.1 \times 10^{7} \mathrm{cfu} / \mathrm{g}$ and $3.0 \times 10^{4}-4.8 \times 10^{8} \mathrm{cfu} / \mathrm{g}$ respectively. Another study showed that the Vibrio spp were found in different street food samples (10) by the margins of $5.2 \times 10^{4}-6.1 \times 10^{6} \mathrm{cfu} / \mathrm{g}$. Surprisingly total viable bacterial load (TVBC) in all the samples observed in this study was almost same, near about $10^{5} \mathrm{cfu} / \mathrm{g}$ whereas coliform, Pseudomonas and fungal count, all were within the range of $10^{4} \mathrm{cfu} / \mathrm{g}$. Vibrio spp. was observed only in two samples within $8.0 \times 10^{4}-9.0 \times 10^{4}$ $\mathrm{cfu} / \mathrm{g}$. On the other hand, range of the growth of Salmonella and Shigella spp. was $6.0 \times 10^{4}-8.0 \times 10^{4} \mathrm{cfu} / \mathrm{g}$ (Table 1). The presence of these pathogenic organisms revealed the possibility of spreading enteric diseases to the consumers. Presence of fungus indicates the presence of various Mycotoxins in the fruit samples that may pose severe threat to the human health. A study conducted by Renata Maria et al., $(2011,34)$ showed variable fungal growth in between $3.8 \times 10^{4}-5.9 \times 10^{4} \mathrm{cfu} / \mathrm{g}$. Overall fungal growth of the pear samples in this study was $8.8 \times 10^{4}$ $9.5 \times 10^{4} \mathrm{cfu} / \mathrm{g}$ which is slightly higher than the previous report (Table 1).

So, this study showed the presence of different types of

TABLE 1. Load of various microorganisms in the pear samples

\begin{tabular}{cccccccc}
\hline & \multicolumn{7}{c}{ Microbiological Load cfu/ml } \\
\cline { 2 - 8 } $\begin{array}{c}\text { Sample } \\
\text { No. }\end{array}$ & $\begin{array}{c}\text { TVBC } \\
(\mathrm{cfu} / \mathrm{g})\end{array}$ & $\begin{array}{c}\text { TCC } \\
(\mathrm{cfu} / \mathrm{g})\end{array}$ & $\begin{array}{c}\text { Staphylococcus } \\
\text { spp (cfu/g) }\end{array}$ & $\begin{array}{c}\text { Salmonella } \\
\text { spp }(\mathrm{cfu} / \mathrm{g})\end{array}$ & $\begin{array}{c}\text { Pseudomonas } \\
\text { spp }(\mathrm{cfu} / \mathrm{g})\end{array}$ & $\begin{array}{c}\text { Fungi } \\
(\mathrm{cfu} / \mathrm{g})\end{array}$ & $\begin{array}{c}\text { Vibrio } \\
\text { spp } \\
(\mathrm{cfu} / \mathrm{g})\end{array}$ \\
\hline Sample-1 & $2.3 \times 10^{5}$ & $4.0 \times 10^{4}$ & Nil & $8.0 \times 10^{4}$ & $6.0 \times 10^{4}$ & $1.5 \times 10^{4}$ & $\mathrm{Nil}$ \\
Sample-2 & $2.1 \times 10^{5}$ & $8.0 \times 10^{4}$ & $9.8 \times 10^{4}$ & Nil & $6.2 \times 10^{4}$ & $2.8 \times 10^{4}$ & $8.0 \times 10^{4}$ \\
Sample-3 & $2.1 \times 10^{5}$ & $9.0 \times 10^{4}$ & $8.9 \times 10^{4}$ & Nil & $3.4 \times 10^{4}$ & $8.8 \times 10^{4}$ & $\mathrm{Nil}$ \\
Sample-4 & $2.4 \times 10^{5}$ & $3.5 \times 10^{4}$ & $2.6 \times 10^{4}$ & Nil & $8.0 \times 10^{4}$ & $9.5 \times 10^{4}$ & $\mathrm{Nil}$ \\
Sample-5 & $2.4 \times 10^{5}$ & $5.6 \times 10^{4}$ & $6.2 \times 10^{4}$ & $6.0 \times 10^{4}$ & $9.0 \times 10^{4}$ & $6.2 \times 10^{4}$ & $9.0 \times 10^{4}$ \\
\hline
\end{tabular}

TVBC $=$ Total Viable Bacterial Count

$\mathrm{TCC}=$ Total Coliform Count 
TABLE 2. Antibiotic Susceptibility pattern of the isolates

\begin{tabular}{ccccccccccc}
\hline Isolates & \multicolumn{2}{c}{ Klebsiella spp } & \multicolumn{2}{c}{ Salmonella spp } & \multicolumn{2}{c}{ Pseudomonas spp. } & \multicolumn{2}{c}{ Staphylococcus spp. } & \multicolumn{2}{c}{ Vibrio spp } \\
\cline { 2 - 10 } Antibiotics & $\mathbf{R}$ & $\mathbf{S}$ & $\mathbf{R}$ & $\mathbf{S}$ & $\mathbf{R}$ & $\mathbf{S}$ & $\mathbf{R}$ & $\mathbf{S}$ & $\mathbf{R}$ & $\mathbf{S}$ \\
\hline AMP $(10 \mu \mathrm{g})$ & $25 \%$ & $75 \%$ & $30 \%$ & $70 \%$ & $100 \%$ & $0 \%$ & $100 \%$ & $0 \%$ & $50 \%$ & $50 \%$ \\
CIP $(5 \mu \mathrm{g})$ & $50 \%$ & $50 \%$ & $60 \%$ & $40 \%$ & $100 \%$ & $0 \%$ & $50 \%$ & $50 \%$ & $70 \%$ & $30 \%$ \\
PIP $(10 \mu \mathrm{g})$ & $25 \%$ & $75 \%$ & $50 \%$ & $50 \%$ & $0 \%$ & $100 \%$ & $100 \%$ & $0 \%$ & $0 \%$ & $100 \%$ \\
CEF $(30 \mu \mathrm{g})$ & $50 \%$ & $50 \%$ & $25 \%$ & $75 \%$ & $0 \%$ & $100 \%$ & ND & ND & $35 \%$ & $65 \%$ \\
AMO $(10 \mu \mathrm{g})$ & $25 \%$ & $75 \%$ & $25 \%$ & $75 \%$ & $100 \%$ & $0 \%$ & $100 \%$ & $1 \%$ & $45 \%$ & $55 \%$ \\
IPM $(30 \mu \mathrm{g})$ & $0 \%$ & $100 \%$ & $0 \%$ & $100 \%$ & $0 \%$ & $100 \%$ & $25 \%$ & $75 \%$ & $20 \%$ & $80 \%$ \\
CHL $(10 \mu \mathrm{g})$ & $50 \%$ & $50 \%$ & $70 \%$ & $30 \%$ & ND & ND & ND & ND & $60 \%$ & $40 \%$ \\
TMP-SUL $(25 \mu \mathrm{g})$ & $25 \%$ & $75 \%$ & $60 \%$ & $40 \%$ & $25 \%$ & $75 \%$ & $25 \%$ & $75 \%$ & $75 \%$ & $25 \%$ \\
GEN $(10 \mu \mathrm{g})$ & $0 \%$ & $100 \%$ & $10 \%$ & $90 \%$ & $50 \%$ & $50 \%$ & $50 \%$ & $50 \%$ & $10 \%$ & $90 \%$ \\
NALI $(30 \mu \mathrm{g})$ & $75 \%$ & $25 \%$ & $80 \%$ & $20 \%$ & $0 \%$ & ND & ND & ND & $75 \%$ & $25 \%$ \\
ERY $(15 \mu \mathrm{g})$ & $50 \%$ & $50 \%$ & $60 \%$ & $40 \%$ & ND & ND & $25 \%$ & $75 \%$ & $55 \%$ & $45 \%$ \\
\hline
\end{tabular}

$\mathrm{AMP}=$ Ampicillin, $\mathrm{AMO}=$ Amoxicillin, $\mathrm{CIP}=$ Ciprofloxacin, $\mathrm{CEF}=$ Ceftriaxone, $\mathrm{NALI}=$ Nalidixic acid, $\mathrm{IPM}=\mathrm{Imipenem}, \mathrm{ERY}=$ Erythromycin, $\mathrm{CHL}=$ Chloramphenicol, TMP/SUL $=$ Trimethoprime-sulfomethoxazole, GEN= Gentamicin, PIP= Piperaciline.

Sensitive- S; Registrant- R; not done- ND;

microorganisms with a high load in the pear samples. There are so many ways by which pathogens may come in contact with the fruits such as the crop land, organic fertilizers, irrigating water, packaging materials, transport vehicles etc. Besides, unhygienic personnel handling and processing of the fruits and their storage in such a condition which favors microbial growth might also account for such spoilage of fruits. The contaminating pathogens are responsible for various types of enteric diseases as well as serious intoxications in human health.

Antibiotic susceptibility patterns of pathogens found in pear samples. Drug resistance is a serious problem in these days that is becoming more and more risky for the global public health. Our study of antibiogram revealed, although some of the isolates were susceptible towards some antibiotics, several other antibiotics were proved ineffective, indicating the risk of the emerging resistant isolates causing health hazards. Almost every isolates were resistant for one or more antibiotics.

In studies conducted by Noor et al. $(11,12)$ showed that Staphylococcus spp. were highly resistant against ampicillin (93\%), piperaciline (75\%), amoxicillin (92\%) and vancomycin. This result is quite consistent with this study (Table: 2). Intestinally, Klebsiella spp. was found to be sensitive against most of the drugs. But completely a different scenario has been found in a previous case, showing higher resistance of Klebsiella spp. against ampicillin (74\%), ciprofloxacin (86\%), piperaciline $(88 \%)$, amoxicillin $(72 \%)$ and ceftriaxone $(97 \%)(11$, 12). High resistance of Vibrio spp. against ampicillin, chloramphenicol, nalidixic acid, trimethoprimsulphametho xazole, tetracycline, cefotaxime has been shown by Acharjee et al. (10); whereas in this study variable susceptibility pattern were obtained against the different antibiotics for Salmonella and Vibrio isolates (Table 2). Pseudomonas spp were resistant against amoxicillin, ciprofloxacin and ampicillin whereas sensitive against ceftriaxone, piperaciline and imipenem (Table 2).

Antibacterial activity of pear samples. Chemically synthesized medicines may have many adverse side effects on our body but natural antimicrobials from the fruits can be used safely in near future as anti infective pharmaceutical products without creating any undesirable effects in our body. Antimicrobial activity of different fruits such as guava, orange, dragon fruit, Malta, apple, has been tested around the world different times (35). Interestingly, in the present study, antibacterial activity was not found in any one of the pear samples against the laboratory isolates of Escherichia coli, Pseudomonas spp., Salmonella spp. and Bacillus spp. However, the findings suggest that the study might be further extended by increasing the number of sample size to confirm and determine the antibacterial activity of the pear samples.

\section{CONCLUSION}

In fine, it can be concluded that the presence of a wide array of microorganisms with a huge load in the different pear samples is a matter of great concern for the consumers. The pathogenic microorganisms present in the commonly consumed pear fruit exhibited resistance against the regular antibiotics which is of significance from the view point of public health. Every possible measure should be taken by the different regulatory bodies to ensure the safe consumption of fruits.

\section{ACKNOWLEDGEMENT}

Authors are thankful to the Department of Microbiology, Stamford University Bangladesh for all 
the technical help.

\section{REFERENCES}

1. Pitt JI, Hocking AD. 2009. Fungi and Food Spoilage, Springer Science \& Business Media, LLC.

2. Hossain SJ, Tsujiyama I, Takasugi M, Islam MA, Biswas RS, Aoshima H. 2008. Total phenolic content, antioxidative, anti-amylase, antiglucosidase, and antihistamine release activities of Bangladeshi fruits. Food Science and Technology Research. 14 (3): 261-268.

3. Rico D, Martín-Diana AB, Barat JM, Barry-Ryan C. 2007. Extending and measuring the quality of fresh-cut fruit and vegetables: a review. Trends Food Sci. Technol. 18: 373-86.

4. Beuchat LR. 1996. Pathogenic microorganisms associated with fresh produce. J. Food Prot. 59: 204-16.

5. Harris LJ, Farber JN, Beuchat LR, Parish ME, Suslow TV, Garrett EH, et al. 2003. Outbreaks associated with fresh produce: incidence, growth, and survival of pathogens in fresh and fresh-cut produce. CRFSFS. 2 (1): 78-141.

6. Ibatsam K, Rukhsana B. 2014. Prevalence of post-harvest rot of fruits and vegetables by Penicillium species. Int. J. Adv. Res. Biol. Sci. 1 (9): 14-19.

7. WHO. 1996. Resistance to antimicrobial agaents. Bull.World Health Org. 71: 335-336.

8. Sumălan RM, Ancuța D, Simonea L, Sumălan R1, Camen D, Carmen B. 2011. Study on fungal load of pome fruits, hazardous factor for quality maintaining and ensuring the consumer safety. Journal of Horticulture, Forestry and Biotechnology. 15 (2): 147- 151.

9. Gerald SM, James GR, Ahmed YE. 2006, Microbiology of Fruits and Vegetables. Taylor and Francis, LLC. P.

10. Acharjee M, Rahman F, Jahan F, Noor R. 2013. Bacterial proliferation in municipal water supplied in mirpur locality of Dhaka city, Bangladesh. Clean - Soil, Air, Water. 42 (4): 434-441.

11. Noor R, Uddin MA, Haq MA, Munshi SK, Acharjee M, Rahman MM 2013. Microbiological study of vendor and packed fruit juices locally available in Dhaka city, Bangladesh. International Food Research Journal. 20 (2): 1011-1015.

12. Noor R, Acharjee M, Ahmed T, Das KK, Paul L, Munshi SK, et al 2013. Microbiological analysis of major sea fish collected from loca markets in Dhaka city, Bangladesh. The Journal of Microbiology, Biotechnology and Food Sciences. 2 (4): 2420-2430.

13. Ahmed T, Baidya S, Sharma BC, Malek Mm, Das KK, Acharjee M, et al. 2013. Identification of drug-resistant bacteria among export quality shrimp samples in Bangladesh. Asian Journal of Microbiology, Biotechnology and Environmental Science. 15 (4): 31-36.

14. Marjan S, Das KK, Munshi SK, Noor R. 2014. Drug-resistant bacteria pathogens in milk and some milk products. Nutrition and Food Science. 44 (3): 241-248.

15. Noor R, Hasan MF, Rahman MM. 2014. Molecular characterization of the virulent microorganisms along with their drug-resistance traits associated with the export quality frozen shrimps in Bangladesh. SpringerPlus, 3: 469 .

16. Malek M, Acharjee M, Rahman T. 2013. Microbiological profile of potato samples collected from Bangladesh Agriculture Research Institute (BARI) and notification of anti-bacterial traits. S. J. Microbiobiol. 3 (1): 21
17. Dutta S, Hasan MR, Rahman, F, Jilani MSA, Noor R. 2013. Study of antimicrobial susceptibility of clinically significant microorganisms isolated from selected areas of Dhaka, Bangladesh. Bangladesh Journal of Medical Science. 12 (1): 34-42.

18. Jilani MSA, Murshed M, Sultana L, Hasan Z. 2008. Common clinically important aerobic bacteria and their antibiotic resistance pattern of Dhaka city and its vicinity. Bangladesh Med. Coll. J. 14: 66-71.

19. Acharjee M, Ahmed E, Munshi SK, Noor R. 2014. Validation of $\gamma$ irradiation in controlling microorganisms in fish. Nutrition and Food Science. 44 (3): 258-266.

20. Shan B, Cai Y, Brooks JD, Corke H. 2007. The in vitro antibacterial activity of dietary spice and medicinal herb extracts. International Journal of Food Microbiology. 117: 112

21. Haslam E. 1996. Natural Polyphenols (Vegetable Tannins) as Drugs: Possible Modes of Action. Journal of Natural Product. 59: 205-215.

22. Jayaprakasha GK, Singh RP, Sakariah KK. 2001. Antioxidant activity of grape seed (Vitis vinifera) extracts on peroxidation model in vitro. Food Chemistry. 73: 285-290.

23. Li Y, Guo C, Yang J, Wei J, Xu J, Cheng S. 2006. Evaluation of antioxidan properties of pomegranate peel extract in comparison with pomegranate pulp extract. Food Chemistry. 96: 254-260

24. Rao AV, and Rao LG. 2007. Carotenoids and human health. Pharmacological Research. 55: 207-216.

25. American Public Health Association (AHPA). 1998. Standard methods for the examination of water and wastewater. Washington, D.C: American Public Health Association.

26. Cappuccino JG, Sherman N. 1996. Microbiology - A Laboratory Manual. The Benjamin/Cummings Publishing Co., Inc., Menlo Park, California.

27. Alfrad EB. 2007. Bensons Microbiological Applications. Mcgraw-Hill Book Company, New York.

28. Bauer A, W, W. M. M. Kirby JC, Sheriss M. Turck. 1966. Antibiotic susceptibility testing by standardized single disc method. Am. J. Clinical pathol. 45: 493-496.

29. Jagessar RC, Mars A, Gones G. 2008. Selective anti-microbial properties of leaf extract against various micro-organism using Disc diffusion and Agar well diffusion method. Journal of nature and science. 6 (2): 24-38.

30. Hussain A, Wahab S, Zarin I, Hussain MDS. 2010. Antibacterial activity of the leaves of Coccinia indica (W. and A) of India. Adv. Biol. Res. 4 (5): 241248

31. Dubey A, Mishra N, Singh N. 2010. Antimicrobial activity of some selected vegetables.Int. J. Appl. Biol. Pharma. Technol. 1 (3): 994-999.

32. Butt AA, Aldridge KE, Sanders CV. 2004. Infections related to the ingestion of seafood part 1: viral and bacterial infections. The Lacent Infectious Diseases. 4: 201-212.

33. Rahman F, Noor R. 2012. Prevalence of pathogenic bacteria in common salad vegetables of Dhaka Metropolis. Bangladesh Journal of Botany. 41 (2): 159162.

34. Sumălan RM, Doncean A, Simonea L, Sumălan R1, Camen D1, Beinsan C. 2011. Study on fungal load of pome fruits, hazardous factor for quality maintaining and ensuring the consumer safety. Journal of Horticulture, Forestry and Biotechnology. 15 (2): 147- 151

35. Anshika M, Neeraj M. 2011. Antimicrobial activity of tropical fruits. Biological Forum - An International Journal. 3 (1): 1-4 